\title{
Inhibition of full length Hepatitis C Virus particles of 1a genotype through small interference RNA
}

Muhammad Ansar ${ }^{2,3 \dagger}$, Usman Ali Ashfaq ${ }^{1 * \dagger}$, Imran shahid ${ }^{3}$, Muhammad Tahir Sarwar ${ }^{3}$, Tariq Javed ${ }^{1}$, Sidra Rehman ${ }^{1}$ , Sajida Hassan ${ }^{3}$ and Sheikh Riazuddin ${ }^{4}$

\begin{abstract}
Background: Hepatitis C virus (HCV), a member of the Flaviviridae family of viruses, is a major cause of chronic hepatitis, liver cirrhosis and hepatocellular carcinoma. Currently, the only treatment available consists of a combination of Pegylated interferon alpha (INF- $\alpha$ ) and ribavirin, but only half of the patients treated show a sufficient antiviral response. Thus there is a great need for the development of new treatments for HCV infections. RNA interference (RNAi) represents a new promising approach to develop effective antiviral drugs and has been extremely effective against HCV infection.
\end{abstract}

Results: This study was design to assess or explore the silencing effect of small interference RNAs (siRNAs) against full length HCV particles of genotype 1a. In the present study six 21-bp siRNAs were designed against different regions of HCV structural genes (Core, E1 and E2). Selected siRNAs were labeled as Csi 301, Csi 29, E1si 52, E1si 192, E2si 86 and E2si 493. Our results demonstrated that siRNAs directed against HCV core gene showed 70\% reduction in viral titer in HCV infected liver cells. Moreover, siRNAs against E1 and E2 envelop genes showed a dramatic reduction in HCV viral RNA, E2si 86 exhibited 93\% inhibition, while E1si 192, E2si 493 and E1si 52 showed 87\%, $80 \%$, and $66 \%$ inhibition respectively. No significant inhibition was detected in cells transfected with the negative control siRNA.

Conclusion: Our results suggested that siRNAs targeted against HCV structural genes efficiently silence full length HCV particles and provide an effective therapeutic option against HCV infection.

\section{Background}

HCV was identified in 1989 as the leading pathogen for non-A, non-B viral hepatitis [1]. HCV is an enveloped positive-single stranded RNA virus $9.6 \mathrm{~kb}$ in length consisting of structural (Core, E1, E2 and possibly p7) proteins and nonstructural (NS2, NS3, NS4A, NS4B, NS5A and NS5B) proteins $[2,3]$. HCV Core is known as the inducer of steatosis, oxidative stress and liver cancer [4]. E1 and E2 are involved in virus attachment with the cells and are considered to be the first viral proteins come in contact with the cells [5]. An estimated more than 170 million individuals worldwide have been chronically infected, while 3-4 million new infections believed to occur each year [6]. Many infected

\footnotetext{
* Correspondence: usmancemb@gmail.com

† Contributed equally

'Division of Molecular Medicine, National Centre of Excellence in Molecular Biology, University of the Punjab, Lahore, Pakistan

Full list of author information is available at the end of the article
}

individuals develop liver damage with an increased risk of progression to fibrosis, cirrhosis, and liver cancer [7].

Currently the standard therapy for $\mathrm{HCV}$ is pegylated interferon (PEG-INF) with nucleoside analog ribavirin (RBV). This therapy achieves $50 \%$ sustained virological response (SVR) for genotype 1, which is the most prevalent form of the virus in the United States, Western Europe and Japan. SVR is $80 \%$ for genotype $2 \& 3$, which is the most prevalent genotype in Pakistan [8-10]. A sustained viral response occurs when there is no trace of HCV RNA present in the patient's blood immediately after treatment and also six months post-treatment. As pegylated interferon is expensive, standard interferon is still the main therapy for HCV treatment in under developed countries. Studies showed that current therapies are costly and cause a variety of side effects, including irritability, headache, flu-like symptoms, anemia, depression and gastrointestinal symptoms [10]. Low response rates and the significant side effect burden of

\section{Biomed Central}

(c) 2011 Ansar et al; licensee BioMed Central Ltd. This is an Open Access article distributed under the terms of the Creative Commons Attribution License (http://creativecommons.org/licenses/by/2.0), which permits unrestricted use, distribution, and reproduction in any medium, provided the original work is properly cited. 
current HCV therapies necessitate the identification of more effective anti-HCV agents, especially for treatment of patients infected with genotype 1a.

RNA interference (RNAi), a post-transcriptional regulation mechanism, is initiated by small interfering RNAs (siRNAs) of 21-23 nucleotides, which are incorporated into a multi-protein complex commonly known as the RNA-induced silencing complex (RISC), leading to sequence-specific degradation of target mRNA recognized by the antisense strand of the siRNA [11-16]. RNAi was first discovered in the nematode worm Caenorrhabditis elegans [11], but it is present in many other organisms such as Drosophila, certain parasitic protozoa, and vertebrates $[17,18]$. Small interference RNA (siRNA) is a valuable tool to inhibit the expression of a target gene in a sequence-specific manner, and may be used for functional genomics, target validation and therapeutic purposes. The difference between antisense approaches and conventional drugs is that the conventional drugs bind to proteins and thereby modulate their function whereas antisense agents act at the mRNA level, preventing its translation into protein $[19,20]$. siRNAs can be used as a potential therapeutic agents against $\mathrm{HCV}$ because $\mathrm{HCV}$ replication takes place in the cytoplasm of liver cells without integration into the host genome. Moreover, its genome functions both as an mRNA and as a replication template. Several reports demonstrated potent RNAi activity against HCV in subgenomic replicon and infection [21-23]. Synthetic or vector based siRNAs targeted against 5' untranslated region (UTR), HCV core, NS3, NS4B and NS5B were found to be effective in reducing viral replication and infection [22-26].

The present study was undertaken to study the effect of siRNAs directed against the structural genes of the HCV genotype 1a in HCV infected liver cells. It demonstrates that the RNAi-mediated silencing of the HCV full length viral particle may be one of the important therapeutic opportunities against HCV 1a genotype.

\section{Materials and methods Serum Sample Collection}

HCV-1a patient's serum samples used in this investigation were obtained from the CAMB (Center for Applied Molecular Biology) diagnostic laboratory, Lahore, Pakistan. Serum samples were stored at $-80^{\circ} \mathrm{C}$ prior to viral inoculation experiments. Quantification and genotype was assessed by CAMB diagnostic laboratory, Lahore, Pakistan. Patient's written consent and approval for this study was obtained from institutional ethics committee.

\section{siRNAs designing}

Small interfering RNA oligonucleotides against $\mathrm{HCV}$ core, envelop protein (E1 and E2) and P7 genes were designed to the most conserved target region of these genes using the Ambion's siRNA design tool http:// www.ambion.com/techlib/misc/siRNA_finder.html. The designed siRNAs against $\mathrm{HCV}$ core, envelop protein (E1 and E2) and P7 genes were synthesized using Silencer siRNA construction kit according to the manufacturer's instruction (Ambion, USA).

\section{Cell line}

The Huh-7 cell line was compassionately offered by Dr. Zafar Nawaz (Biochemistry and Molecular Biology Department, University of Miami, USA). Huh-7 cells were cultured in Dulbecco's modified Eagle medium (DMEM) supplemented with 10\% fetal bovine serum \& $100 \mathrm{IU} / \mathrm{ml}$ penicillin \& $100 \mu \mathrm{g} / \mathrm{ml}$ streptomycin, at $37^{\circ} \mathrm{C}$ in an atmosphere of $5 \% \mathrm{CO}_{2}$.

\section{MTT assay for toxicity}

To investigate cellular toxicity, $2 \times 10^{4}$ cells/well was plated into 96-well plates. After $24 \mathrm{~h}$, different concentrations of siRNAs were added and the plate was sealed and kept at $37^{\circ} \mathrm{C}$ in an atmosphere of $5 \% \mathrm{CO}^{2}$ for $24 \mathrm{~h}$. After the siRNAs treatment were over, removed the media and siRNAs. About $100 \mu \mathrm{l}$ fresh media and $20 \mu \mathrm{l}$ of MTT solution (5 $\mathrm{mg} / \mathrm{ml}$ in PBS) were added to all wells in Columns 1-11. Wrapped the plate in aluminum foil and incubated for $3-4 \mathrm{~h}$ at $37^{\circ} \mathrm{C}$. Media was carefully removed and added $100 \mu \mathrm{l}$ of DMSO to dissolve the formazan crystals in Columns 1-11. MTT formazan product was determined by measuring absorbance with an enzyme-linked immunosorbent assay (ELISA) plate reader at a test wavelength of $570 \mathrm{~nm}$ and a reference wavelength of $620 \mathrm{~nm}$.

Cell viability was obtained using the following equation:

Percent cell viability $=($ Test $570 \mathrm{~nm}-620 \mathrm{~nm} /$ Control $570 \mathrm{~nm}-620 \mathrm{~nm}) * 10$

\section{Silencing effect of siRNAs in serum infected liver cells}

Huh-7 cell line was used to establish the in-vitro replication of HCV. A similar protocol was used for viral inoculation as established by Zekari et al. 2009 [27] and El-Awardy et al. 2006 [28]. High viral titer $>1 \times 10^{8}$ IU/ $\mathrm{ml}$ from HCV-1a patient's was used as principle inoculum in these experiments. Huh-7 cells were maintained in 6-well culture plates to semi-confluence, washed twice with serum-free medium, then inoculated with $500 \mu \mathrm{l}\left(5 \times 10^{7} \mathrm{IU} /\right.$ well $)$ and $500 \mu \mathrm{l}$ serum free media. Cells were maintained overnight at $37^{\circ} \mathrm{C}$ in $5 \% \mathrm{CO}_{2}$. Next day, adherent cells were washed three times with 1 $\times$ PBS, complete medium was added and incubation was continued for $48 \mathrm{~h}$. Cells were harvested and assessed for viral RNA quantification by Real Time PCR. To analyze the effect of siRNAs on HCV infection, serum infected Huh-7 cells were again seeded after three days 
of infection in 24-well plates in the presence and absence of siRNAs and grown to $80 \%$ confluence. After $48 \mathrm{~h}$, cells and total RNA was isolated by using Gentra RNA isolation kit (Gentra System Pennsylvania, USA) according to the manufacturer's instructions. Briefely, cells were lysed with cell lysis solution containing $5 \mu \mathrm{l}$ internal control (Sacace Biotechnologies Caserta, Italy). RNA pallet was solubilized in 1\% DEPC (Diethyl pyrocarbonate treated water). HCV RNA quantifications were determined by Real Time PCR Smart Cycler II system (Cepheid Sunnyvale, USA) using the Sacace HCV quantitative analysis kit (Sacace Biotechnologies Caserta, Italy) according to the manufacturer's instructions.

Formula for the calculation of HCV RNA concentration Following formula was used to calculate the concentration HCV RNA of each sample.

$$
\frac{\text { Cy3STD } / \text { Res }}{\text { Fam. STD } / \text { Res }} \times \text { coefficient IC }=\mathrm{IU} \mathrm{HCV} / \mathrm{mL}
$$

$\mathrm{IC}=$ internal control, which is specific for each lot.

\section{Statistical Analysis}

All statistical analysis was done using SPSS software (version 11.0, SPSS Inc). Data is presented as mean \pm SE. Numerical data was analyzed using student's t-test and ANOVA. P value $<0.05$ was considered statistically significant.

\section{Results}

Toxicological analysis of siRNAs

Before starting the antiviral screening against HCV, toxicological effect of siRNAs were determined through MTT cell proliferation assay. The MTT substance is

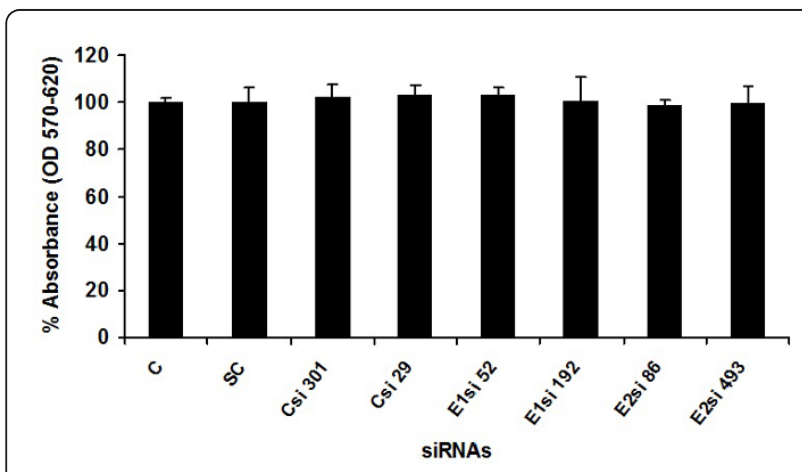

Figure 1 Toxicity of siRNAs through MTT cell proliferation assay. Huh-7 cells were plated at the density of $2 \times 10^{4}$ in 96 well plates. After $24 \mathrm{~h}$ cells were treated with different concentrations of siRNAs and control consisted of solvent in which siRNAs dissolved. After $24 \mathrm{~h}$ incubation period add MTT solution to all wells and incubated for $3-4 \mathrm{~h}$ at $37^{\circ} \mathrm{C}$. Viable cells convert MTT to purple formazan crystal. Added DMSO to dissolve the formazan crystals and read absorbance at $570 \mathrm{~nm}$ and $620 \mathrm{~nm}$. reduced by mitochondrial succinic dehydrogenases in living cells to purple formazan crystals that are not soluble in aqueous water. The absorption of dissolved formazan in the visible region correlates with the number of alive cells [29]. Figure 1 shows cytotoxicity analysis of siRNAs and demonstrates that Huh7 cells viability is unaffected at a concentration of $20 \mu \mathrm{M}$ (Figure 1).

\section{Silencing effect of siRNAs on liver infected cells}

The ability of siRNAs to inhibit HCV replication and infection was evaluated by designing and constructing siRNAs against different sites of HCV structural genes having genotype1a (Core, E1 and E2). siRNAs targeting sites were selected in regions conserved among different samples. Selected siRNAs were labeled as Csi 301, Csi 29, E1si 52, E1si 192, E2si 86 and E2si 493. Negative control siRNA (scrambled siRNA) with the same nucleotide composition as the experimental siRNA which lacks significant sequence homology to the HCV and human genome was designed (Table 1). The results indicate that siRNAs targeting HCV structural genes have the ability to inhibit the whole virus of 1a genotype in serum infected liver cells. The effect of gene-specific siRNAs against the whole virus was evaluated in seruminfected Huh-7 cells by measuring reduction in the HCV RNA titer. Real-time PCR results showed that core siRNAs (Csi 301 and Csi 29) reduced HCV-1a RNA level up to $70 \%$ (Figure 2). siRNAs against E1 and E2 envelop genes showed a dramatic reduction in $\mathrm{HCV}$ viral RNA, E2si 86 showed a maximum inhibition of about 93\%, while E1si 192, E2si 493 and E1si 52 showed $87 \%, 80 \%$, and $66 \%$ inhibition respectively (Figure 3). Together, these data suggest a negative impact of chemically synthesized Core and envelop genes siRNAs on $\mathrm{HCV}$ replication and infection that could be used for the down regulation of the whole viral particle of $\mathrm{HCV}$ la genotype. This result was in accordance with Zekri et

Table 1 Sequence of siRNA oligonucleotides directed against structural genes of HCV 1 a genotype

\begin{tabular}{lll}
\hline SN & siRnAs Name & Sequence 5'-3' $^{\prime}$ \\
\hline 1 & Csi 29-antisense & AAACCAAACGTAACACCAACCCCTGTCTC \\
2 & Csi 29-sense & AAGGTGGTGTTACGTTGGTCCTGTCTC \\
3 & Csi 301-antisense & AAGGTCATCGATACCCTTACGCCTGTCTC \\
4 & Csi 301-sense & AACGTAAGGGTATCGATGACCCCTGTCTC \\
5 & E1si 52-antisense & AACTCGAGTATTGTGTACGAGCCTGTCTC \\
6 & E1si 52-sense & AACTCGTACACAATACTCGAGCCTGTCTC \\
7 & E1si 192-antisense & AACGCAGCTTCGACGTCATATCCTGTCTC \\
8 & E1si 192-sense & AAATATGACGTCGAAGCTGCGCCTGTCTC \\
9 & E2si 86-antisense & AACTGATCAACACCAACGGCACCTGTCTC \\
10 & E2si 86-sense & AATGCCGTGGTGTGATCAGCCTGTCTC \\
11 & E2si 493-antisense & AATTGGTCGGTTGTACCTGGCCTGTCTC \\
12 & E2si 493-sense & AACCAGGTACAACCGAACCAACCTGTCTC \\
\hline
\end{tabular}




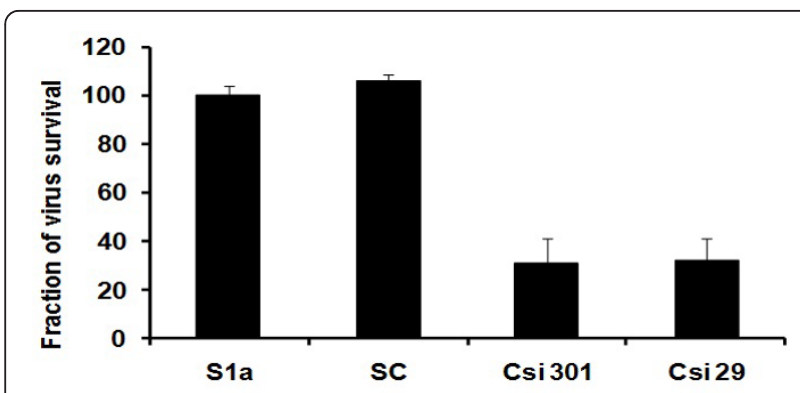

Figure 2 Silencing effect of core specific siRNAs against full length viral particles of HCV 1a genotype. Huh-7 cells were infected with high titer sera sample from HCV-1a patients (S1a) to establish in vitro cell culture model of HCV-1a, cells were maintained overnight at $37^{\circ} \mathrm{C}$ in $5 \% \mathrm{CO} 2$ for three days. Cells were harvested after siRNA treatment 48 hrs post transfection and intracellular HCV RNA levels were quantified by Real Time PCR. Data is expressed as percentage of HCV survival in cells. S1a means control consisted of HCV serum of 1a genotype) and SC means scrambled siRNA. Error bars indicate, mean S.D $p<0.05$ verses S1a.

al. 2009 [27] who also showed best inhibitory effect of siRNAs against 5 'UTR on 3rd day of post-transfection.

\section{Discussion}

$\mathrm{HCV}$ is a leading cause of acute and chronic hepatitis which can eventually lead to permanent liver damage, hepatocellular carcinoma and death. Currently, there is no vaccine available for prevention of $\mathrm{HCV}$ infection due to high degree of strain variation. The only therapy available is a combination of interferon and ribavirin, which cure only $50 \%$ of patients having genotype $1 \mathrm{a}$. RNA interference (RNAi) represents a new promising approach to develop effective antiviral drugs against

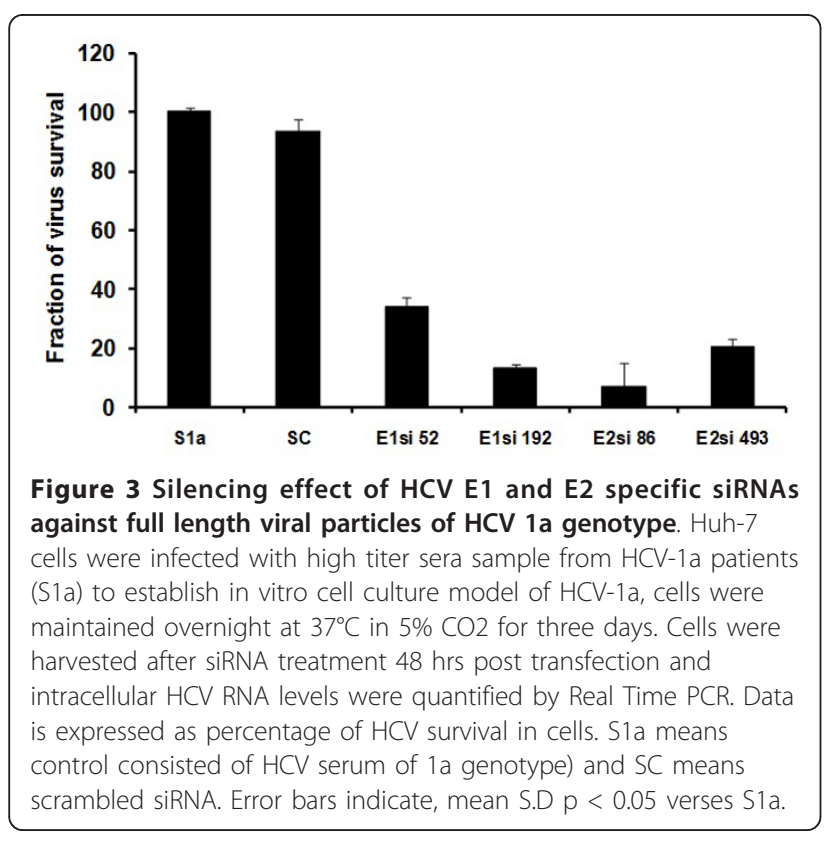

$\mathrm{HCV}$. In order to identify potent anti-HCV agents, many investigators design and test multiple oligonucleotides that target different sites and regions of the target mRNA and many of them show desired results [30]. The underlying mechanism of siRNA-mediated gene silencing is still unknown in mammalian cells; it could interfere with RNA stability and/or translation or, alternatively, transcription. In cultured mammalian cell lines, chemically synthesized siRNAs can be introduced into cells when formulated with lipophilic reagents [31]. Longer dsRNAs (50 bp) have a more broad effect in mammalian somatic cells, resulting in general arrest of protein synthesis through interferon response and also protein kinase activation. In contrast, shorter siRNAs of 21-23 nt have a more specific effect, inducing up to $90 \%$ suppression of specific mRNAs both in vitro and in vivo $[12,22]$. Due to its high suppression efficiency and sequence specificity up to a single nucleotide resolution [13] has encouraged the development of RNAi-based therapeutic models for possible use in viral infections $i$. e. HIV-1 [32], HBV [22], HCV [22], respiratory viruses [33] and cancer i.e. K-ras [34], PI 3-kinase [31]. The $\mathrm{HCV}$ genome is a positive-sense single-stranded RNA that functions as both a messenger RNA and replication template via a negative-strand intermediate, making it an attractive target for the study of RNA interference.

A potential problem that may arise in RNAi based approach is the error prone nature of $\mathrm{HCV}$ genome with generation of quasispecies during chronic $\mathrm{HCV}$ infection but this problem can be overcome by designing siRNAs against highly conserved region of $\mathrm{HCV}$ [35-37]. Several reports demonstrated that RNAi, efficiently inhibits viral replication and infection by targeting 5'UTR, Core, E1, E2, NS3, NS4b and NS5b sequences as alternative anti-HCV strategies $[23,25$, $35,38-40]$. Two different groups used siRNA against Core gene of HCV 1a and 1b genotype and observed $60 \%$ and $80 \%$ reduction in mRNA and protein expression respectively [40,41]. A study demonstrated that siRNAs targeted against E2, NS3 and NS5B regions effectively inhibit core gene expression [41] and Kim et al., 2006, has designed siRNAs against HCV 1b and 1a genome to explore the silencing of structural genes and showed significantly less expression in a dose-dependent manner. In the present study, six different siRNAs were designed, with GC content of $35-50 \%$, targeting structural genes of HCV 1a genotype.

The plaque assay is the most important procedure in virology to measure virus infectious titers by visualizing the viral-induced cytopathic effect. However, plaque assay for HCV is not available because HCV is noncytopathic and detection of $\mathrm{HCV}$-infected cells commonly rely on visualization of the infected cells by immunostaining of $\mathrm{HCV}$ proteins [42], western blotting 
and RT PCR. Recently, different groups have studied $\mathrm{HCV}$ replication in serum-infected liver cell lines, which mimics the naturally occurring $\mathrm{HCV}$ infection in humans $[28,43,44]$. In this study, Huh-7 cells were infected with native viral particles from HCV-genotype1a positive serum, using the same protocol as described by El-Awady et al., and Zekri et al. [27,28]. siRNAs against $\mathrm{HCV}-1$ a structural genes used in the present study were screened against HCV-serum-infected Huh-7 cells. An exciting finding of this study was a decrease in the $\mathrm{HCV}$ viral titer to a maximum of $93 \%$ after treatment with gene-specific siRNAs (E1si 88). siRNAs against HCV core gene (Csi 301, Csi 29) showed up to $70 \%$ inhibition in the viral titer of HCV 1a genotype (Figure 2). Similarly siRNAs directed against HCV envelop proteins (E1si 192, E2si 493 and E1si 52) showed $87 \%, 80 \%$, and $66 \%$ inhibition in the viral titer of genotype 1a respectively (Figure 3 ). These results are in agreement with previous studies, which have suggested that siRNA is the most efficient nucleic-acidbased antiviral approach that can be utilized to degrade the HCV genome in infected cells.

In conclusion, current therapy for $\mathrm{HCV}$ infection is mainly the combination use of interferon and ribavirin, but only about half of the treated patients obtain a sustained antiviral response. Our data suggest that siRNAs targeting HCV structural genes can target viral RNA in infected cells, potentially providing an efficient therapeutic option against $\mathrm{HCV}$ infection.

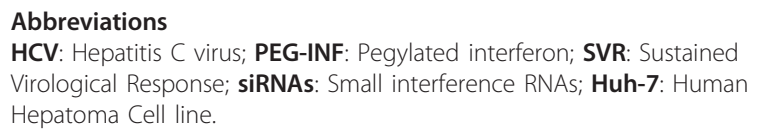

\section{Acknowledgements}

Financial support by Higher Education Commission Pakistan is highly acknowledged.

\section{Author details \\ 'Division of Molecular Medicine, National Centre of Excellence in Molecular Biology, University of the Punjab, Lahore, Pakistan. ${ }^{2}$ Department of Human Genetics, Radboud University Nijmegen Medical Centre, Nijmegen, The Netherlands. ${ }^{3}$ Applied and Functional Genomics Laboratory, National Center of Excellence in Molecular Biology, University of Punjab, Lahore, Pakistan. ${ }^{4}$ Allama Iqbal Medical College, Allama Shabir Ahmad Usmani Road, Lahore, Pakistan.}

\section{Authors' contributions}

MA, UAA and MI contributed equally in lab work and manuscript write up. MTS, TJ and SDR helped me in writing the manuscript. SH and SRD was the principal investigator and provides all facilities to complete this work. All the authors read and approved the final manuscript.

\section{Authors' information}

Muhammad Ansar (PhD Scholar), Usman Ali Ashfaq (PhD Molecular Biology), Imran shahid (M Phil Molecular Biology), Muhammad Tahir Sarwar (PhD scholar), Tariq Javed (M. Phil pharmaceutical chemistry, Sidra Rehman (MSC Chemistry), Sajida Hassan (PhD Molecular Biology) and Sheikh Riazuddin (PhD molecular Biology and Dean Post graduate study at Allama Iqbal medical college, Lahore

\section{Competing interests}

The authors declare that they have no competing interests.

Received: 28 January 2011 Accepted: 2 May 2011 Published: 2 May 2011

\section{References}

1. Choo QL, Kuo G, Weiner AJ, Overby LR, Bradley DW, Houghton M: Isolation of a cDNA clone derived from a blood-borne non-A, non-B viral hepatitis genome. Science 1989, 244:359-362.

2. Lin C, Lindenbach BD, Pragai BM, McCourt DW, Rice CM: Processing in the hepatitis C virus E2-NS2 region: identification of $\mathrm{p} 7$ and two distinct E2specific products with different C termini. J Virol 1994, 68:5063-5073.

3. Reed KE, Rice CM: Overview of hepatitis $C$ virus genome structure, polyprotein processing, and protein properties. Curr Top Microbiol Immunol 2000, 242:55-84.

4. Moriya K, Nakagawa K, Santa T, Shintani Y, Fujie H, Miyoshi H, Tsutsumi T, Miyazawa T, Ishibashi K, Horie T, et al: Oxidative stress in the absence of inflammation in a mouse model for hepatitis $C$ virus-associated hepatocarcinogenesis. Cancer Res 2001, 61:4365-4370.

5. Liu Q, Tackney C, Bhat RA, Prince AM, Zhang P: Regulated processing of hepatitis $C$ virus core protein is linked to subcellular localization. $J$ Virol 1997, 71:657-662.

6. WHO: World Health Organization. Department of Measurement and Health Information. 2004 [http://www.who.int/healthinfo/statistics/ bodgbddeathdalyestimates.xls].

7. Memon Ml, Memon MA: Hepatitis C: an epidemiological review. J Viral Hepat 2002, 9:84-100.

8. Manns MP, McHutchison JG, Gordon SC, Rustgi VK, Shiffman M Reindollar R, Goodman ZD, Koury K, Ling M, Albrecht JK: Peginterferon alfa- $2 b$ plus ribavirin compared with interferon alfa- $2 b$ plus ribavirin for initial treatment of chronic hepatitis C: a randomised trial. Lancet 2001, 358:958-965.

9. Di Bisceglie AM, Hoofnagle JH: Optimal therapy of hepatitis C. Hepatology 2002, 36:5121-127.

10. Fried MW, Shiffman ML, Reddy KR, Smith C, Marinos G, Goncales FL Jr, Haussinger D, Diago M, Carosi G, Dhumeaux D, et al: Peginterferon alfa-2a plus ribavirin for chronic hepatitis C virus infection. N Engl J Med 2002, 347:975-982.

11. Fire A, Xu S, Montgomery MK, Kostas SA, Driver SE, Mello CC: Potent and specific genetic interference by double-stranded RNA in Caenorhabditis elegans. Nature 1998, 391:806-811.

12. Elbashir SM, Harborth J, Lendeckel W, Yalcin A, Weber K, Tuschl T: Duplexes of 21-nucleotide RNAs mediate RNA interference in cultured mammalian cells. Nature 2001, 411:494-498.

13. Elbashir SM, Lendeckel W, Tuschl T: RNA interference is mediated by 21and 22-nucleotide RNAs. Genes Dev 2001, 15:188-200.

14. Elbashir SM, Martinez J, Patkaniowska A, Lendeckel W, Tuschl T: Functional anatomy of siRNAs for mediating efficient RNAi in Drosophila melanogaster embryo lysate. Embo J 2001, 20:6877-6888.

15. Hannon GJ: RNA interference. Nature 2002, 418:244-251.

16. Cullen BR: RNA interference: antiviral defense and genetic tool. Nat Immunol 2002, 3:597-599.

17. Sharp PA: RNA interference-2001. Genes Dev 2001, 15:485-490

18. Tuschl T: RNA interference and small interfering RNAs. Chembiochem 2001, 2:239-245.

19. Scherer LJ, Rossi JJ: Approaches for the sequence-specific knockdown of mRNA. Nat Biotechnol 2003, 21:1457-1465.

20. Sahu NK, Shilakari G, Nayak A, Kohli DV: Antisense technology: a selective tool for gene expression regulation and gene targeting. Curr Pharm Biotechnol 2007, 8:291-304.

21. Randall G, Panis M, Cooper JD, Tellinghuisen TL, Sukhodolets KE, Pfeffer S, Landthaler M, Landgraf $\mathrm{P}$, Kan S, Lindenbach BD, et al: Cellular cofactors affecting hepatitis $C$ virus infection and replication. Proc Natl Acad Sci USA 2007, 104:12884-12889.

22. McCaffrey AP, Meuse L, Pham TT, Conklin DS, Hannon GJ, Kay MA: RNA interference in adult mice. Nature 2002, 418:38-39.

23. Kapadia SB, Brideau-Andersen A, Chisari FV: Interference of hepatitis C virus RNA replication by short interfering RNAs. Proc Natl Acad Sci USA 2003, 100:2014-2018.

24. Randall G, Chen L, Panis M, Fischer AK, Lindenbach BD, Sun J, Heathcote J, Rice CM, Edwards AM, McGilvray ID: Silencing of USP18 potentiates the 
antiviral activity of interferon against hepatitis $\mathrm{C}$ virus infection. Gastroenterology 2006, 131:1584-1591.

25. Wilson JA, Jayasena S, Khvorova A, Sabatinos S, Rodrigue-Gervais IG, Arya S, Sarangi F, Harris-Brandts M, Beaulieu S, Richardson CD: RNA interference blocks gene expression and RNA synthesis from hepatitis $C$ replicons propagated in human liver cells. Proc Natl Acad Sci USA 2003, 100:2783-2788.

26. Takigawa Y, Nagano-Fujii M, Deng L, Hidajat R, Tanaka M, Mizuta H, Hotta H: Suppression of hepatitis C virus replicon by RNA interference directed against the NS3 and NS5B regions of the viral genome. Microbiol Immunol 2004, 48:591-598.

27. Zekri AR, Bahnassy AA, El-Din HM, Salama HM: Consensus siRNA for inhibition of HCV genotype-4 replication. Virol J 2009, 6:13.

28. el-Awady MK, Tabll AA, el-Abd YS, Bahgat MM, Shoeb HA, Youssef SS, Bader el-Din NG, Redwan el RM, el-Demellawy M, Omran MH, et al: HepG2 cells support viral replication and gene expression of hepatitis $C$ virus genotype 4 in vitro. World J Gastroenterol 2006, 12:4836-4842.

29. Mosmann T: Rapid colorimetric assay for cellular growth and survival: application to proliferation and cytotoxicity assays. J Immunol Methods 1983, 65:55-63.

30. Khaliq S, Khaliq SA, Zahur M, Ijaz B, Jahan S, Ansar M, Riazuddin S, Hassan S: RNAi as a new therapeutic strategy against HCV. Biotechnol Adv 28:27-34.

31. Caplen NJ, Parrish S, Imani F, Fire A, Morgan RA: Specific inhibition of gene expression by small double-stranded RNAs in invertebrate and vertebrate systems. Proc Natl Acad Sci USA 2001, 98:9742-9747.

32. Shin D, Lee H, Kim Sl, Yoon Y, Kim M: Optimization of linear doublestranded RNA for the production of multiple siRNAs targeting hepatitis C virus. Rna 2009, 15:898-910.

33. Bitko V, Musiyenko A, Shulyayeva O, Barik S: Inhibition of respiratory viruses by nasally administered siRNA. Nat Med 2005, 11:50-55.

34. Brummelkamp TR, Bernards R, Agami R: A system for stable expression of short interfering RNAs in mammalian cells. Science 2002, 296:550-553.

35. Prabhu R, Vittal P, Yin Q, Flemington E, Garry R, Robichaux WH, Dash S: Small interfering RNA effectively inhibits protein expression and negative strand RNA synthesis from a full-length hepatitis C virus clone. J Med Virol 2005, 76:511-519.

36. Wilson JA, Richardson CD: Hepatitis $C$ virus replicons escape RNA interference induced by a short interfering RNA directed against the NS5b coding region. J Virol 2005, 79:7050-7058.

37. Watanabe T, Umehara T, Yasui F, Nakagawa $S$, Yano J, Ohgi T, Sonoke $S$, Satoh K, Inoue K, Yoshiba M, Kohara M: Liver target delivery of small interfering RNA to the HCV gene by lactosylated cationic liposome. J Hepatol 2007, 47:744-750

38. Seo MY, Abrignani S, Houghton M, Han JH: Small interfering RNAmediated inhibition of hepatitis $C$ virus replication in the human hepatoma cell line Huh-7. J Virol 2003, 77:810-812.

39. Yokota T, Sakamoto N, Enomoto N, Tanabe Y, Miyagishi M, Maekawa S, Yi L, Kurosaki M, Taira K, Watanabe M, Mizusawa H: Inhibition of intracellular hepatitis $C$ virus replication by synthetic and vector-derived small interfering RNAs. EMBO Rep 2003, 4:602-608.

40. Kim M, Shin D, Kim SI, Park M: Inhibition of hepatitis C virus gene expression by small interfering RNAs using a tri-cistronic full-length viral replicon and a transient mouse model. Virus Res 2006, 122:1-10.

41. Liu M, Ding H, Zhao P, Qin ZL, Gao J, Cao MM, Luan J, Wu WB, Qi ZT: RNA interference effectively inhibits mRNA accumulation and protein expression of hepatitis C virus core and E2 genes in human cells. Biosci Biotechnol Biochem 2006, 70:2049-2055.

42. Zhong J, Gastaminza P, Cheng G, Kapadia S, Kato T, Burton DR, Wieland SF, Uprichard SL, Wakita T, Chisari FV: Robust hepatitis C virus infection in vitro. Proc Natl Acad Sci USA 2005, 102:9294-9299.

43. Lazaro CA, Chang M, Tang W, Campbell J, Sullivan DG, Gretch DR, Corey L, Coombs RW, Fausto N: Hepatitis C virus replication in transfected and serum-infected cultured human fetal hepatocytes. Am J Pathol 2007, 170:478-489.

44. Buck M: Direct infection and replication of naturally occurring hepatitis $C$ virus genotypes 1, 2, 3 and 4 in normal human hepatocyte cultures. PLoS One 2008, 3:e2660.

doi:10.1186/1743-422X-8-203

Cite this article as: Ansar et al: Inhibition of full length Hepatitis C Virus particles of 1a genotype through small interference RNA. Virology Journal 2011 8:203.

\section{Submit your next manuscript to BioMed Central and take full advantage of:}

- Convenient online submission

- Thorough peer review

- No space constraints or color figure charges

- Immediate publication on acceptance

- Inclusion in PubMed, CAS, Scopus and Google Scholar

- Research which is freely available for redistribution

Submit your manuscript at www.biomedcentral.com/submit
Biomed Central 